\title{
Hubungan Miopia dengan Prestasi Akademik dan Pola Melihat Dekat pada Mahasiswa Fakultas Kedokteran Universitas Riau
}

\author{
Elda Nazriati ${ }^{1}$, Chandra Wijaya ${ }^{2}$
}

\begin{abstract}
Prevalence rates of myopia in many Asian urban countries reaching epidemic proportion. It has long been observed that myopic children have higher IQ, and association between myopia and higher level of near work. This study aims to quantify the association myopia with school achievement and near work in Riau University medical students. The prevalence rate of myopia in Riau University medical students was $31.4 \%$ (76 students). Myopia students as cases group compare to emmetropic students as control group. This study showed that high significant association myopia with near work profile and no significant association myopia with school achievement. Myopia students more likely to have risk near work profile than emmetropic students $\left(\mathrm{x}^{2}\right.$ test $\left.\mathrm{P}<0.001\right)$ with odds ratio 6.12. Myopia students more likely to have high GPA than emmetropic students (OR 1.34) but interaction between myopia and school achievement were not significant $\left(\mathrm{x}^{2}\right.$ test $\left.\mathrm{p}>0.05\right)$.
\end{abstract}

Keywords: Myopia, near work, school achievement

Mata merupakan jalur informasi utama dari panca indera. Adanya kelainan refraksi akan menurunkan produktifitas dan menimbulkan keluhan seperti sakit kepala dan menghambat kelancaran aktifitas sehari-hari. Kelainan refraksi khususnya miopia hampir menjadi epidemik di negara Asia. Penelitian di Australia menunjukkan prevalensi kelainan refraksi terjadi pada usia yang lebih rendah dibandingkan di Negara Eropa dan Amerika. ${ }^{1,2,3}$ Gangguan penglihatan akibat kelainan refraksi di Indonesia sebesar $22,1 \%$, sementara angka pemakaian kacamata koreksi masih rendah yaitu $12,5 \%$ dari kebutuhan. ${ }^{4}$

Ada banyak faktor yang diduga sebagai penyebab miopia, faktor genetik berperan $86 \%, 5,6$ tinggi badan dan obesitas juga berhubungan dengan beberapa kondisi mata. ${ }^{1}$ Telah lama diamati di beberapa Negara seperti Israel, Amerika, dan New Zealand bahwa miopia sering terjadi pada anak yang mempunyai Intelligence Quotient (IQ) yang tinggi. ${ }^{7}$

\footnotetext{
1. Penulis untuk korespondensi: Bagian Fisiologi Kedokteran Fakultas Kedokteran Universitas Riau, Alamat: Jl.Diponegoro No.1, Pekanbaru. Telp: 0761- 839264 ext 209.

2. Bagian Fisiologi Kedokteran Fakultas Kedokteran Universitas Riau
}

Beberapa penelitian telah menyebutkan bahwa anakanak yang sering menggunakan mata untuk melihat dalam jarak dekat lebih sering menderita miopia. Waktu belajar yang lama di sekolah-sekolah terbukti mempertinggi angka miopia di Asia. Rendahnya aktifitas fisik dan lebih menyukai menonton televisi juga mempengaruhi terjadinya kelainan refraksi. ${ }^{8}$

Mahasiswa Fakultas Kedokteran umumnya memiliki kecerdasan di atas rata-rata. Banyaknya materi yang harus dikuasai oleh seorang mahasiswa Fakultas Kedokteran menuntut mahasiswa untuk membaca dalam waktu yang lebih banyak. Penelitian Woo dkk menunjukkan pada mahasiswa Fakultas Kedokteran di Singapura prevalensi miopia $89,8 \%$, astigmatisma $82,2 \%$, dan hiperopia $1,3 \%$. Studi lain di Taiwan mendapatkan miopia terjadi pada lebih dari 90\% mahasiswa Fakultas Kedokteran. Di Denmark dan Norwegia miopia terjadi pada 50\% mahasiswa Fakultas Kedokteran. ${ }^{9}$

Berdasarkan latar belakang di atas penulis tertarik untuk meneliti kelainan refraksi khususnya miopia pada mahasiswa Fakultas Kedokteran. Penelitian ini bertujuan untuk melihat prevalensi miopia pada mahasiswa fakultas kedokteran UR serta bagaimana hubungan miopia dengan prestasi 
akademik dan pola melihat dekat pada mahasiswa Fakultas Kedokteran UR.

\section{METODE}

Penelitian ini merupakan penelitian cross sectional comparative. untuk mencari hubungan miopia dengan prestasi akademik dan pola melihat dekat serta membandingkan antara kelompok mahasiswa miopia dan kelompok mahasiswa emetropia. Populasi penelitian ini adalah mahasiswa FK UR angkatan 2007, 2006, dan 2005 yang tercatat sebagai mahasiswa aktif yang berjumlah 242 orang. Pada penelitian ini didapatkan subyek penelitian mahasiswa yang menderita miopia berjumlah 76 orang, sebagai kontrol digunakan 76 orang mahasiswa yang emetropia.

Kelainan refraksi ditentukan dengan menggunakan optotipe snellen, dan lensa optik. Prestasi akademik ditentukan oleh Indeks Prestasi Kumulatif (IPK) mahasiswa. Prestasi akademik digolongkan cukup dan baik berdasarkan cut of point subyek penelitian. Untuk mendapatkan data tentang pola melihat dekat dan data tambahan lainnya subyek penelitian diminta untuk mengisi kuesioner. Pola melihat dekat digolongkan baik dan berrisiko berdasarkan cut of point dari skor pola melihat dekat yang diambil melalui kuesioner pada subyek penelitian.

Data yang diperoleh diolah dan dianalisis dengan analisis univariat dan bivariat menggunakan program SPSS. Hubungan miopia dengan prestasi akademik dan pola melihat dekat di uji dengan uji Chi square. Untuk menilai seberapa sering risiko terjadi pada kelompok kasus dibandingkan kelompok kontrol digunakan rumus Odds Ratio (OR).

\section{HASIL}

Hasil penelitian menunjukkan dari 242 Mahasiswa Fakultas Kedokteran UR terdapat 82 orang $(33,9 \%)$ yang menderita kelainan refraksi yang terdiri dari 76 orang $(31,40 \%)$ berupa miopía, 1 orang $(1,004 \%)$ hipermetropia, dan 5 orang $(0,02 \%)$ astigmatisma tanpa kelainan refraksi lain. Adapun profil miopía pada mahasiswa FK UR tercantum pada Gambar 1 dan 2.

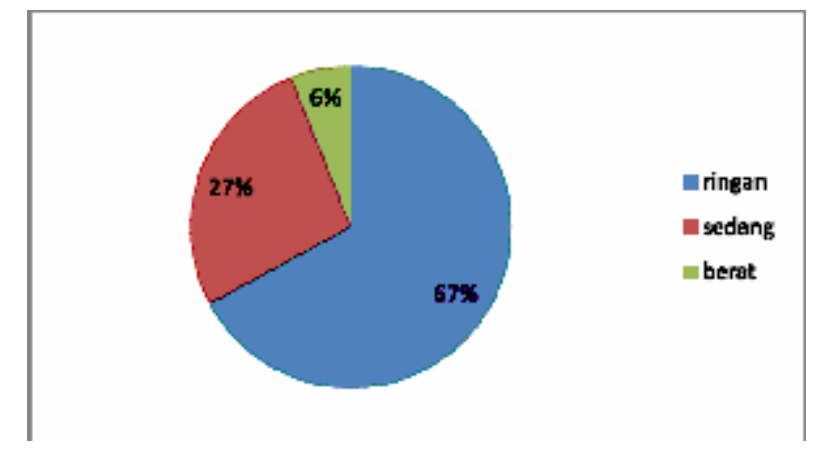

Gambar 1. Profil Miopía berdasarkan berat-ringannya

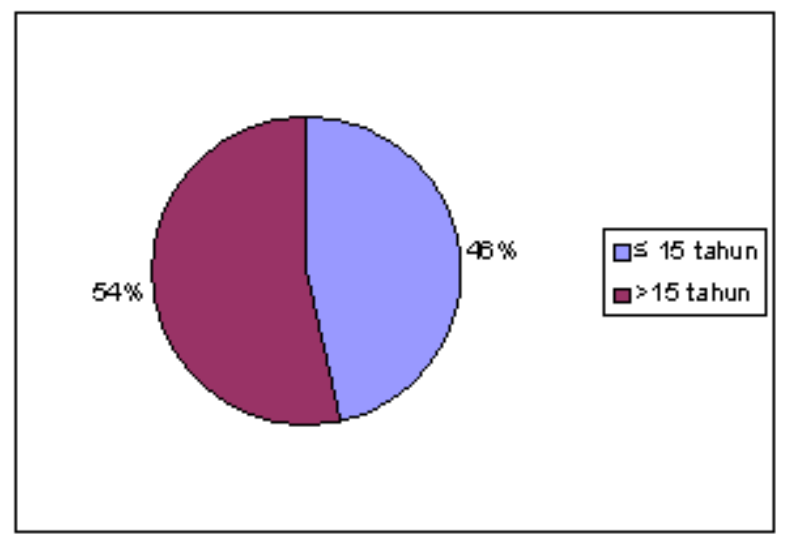

Gambar2. Profil Mahasiswa miopía FK UR berdasarkan umur mulai berkacamata

Dari 11 pertanyaan tentang pola melihat dekat yang ditanyakan kepada 152 subyek penelitian didapatkan Cut of point untuk skor pola melihat dekat adalah 7,00. dengan skor pola melihat dekat $<7,00$ digolongkan pola melihat dekat baik, sedangkan subyek penelitian dengan skor pola melihat dekat $\geq 7,00$ digolongkan pola melihat dekat berrisiko. Profil pola melihat dekat pada mahasiswa FK UR disajikan dalam Gambar 3 berikut:

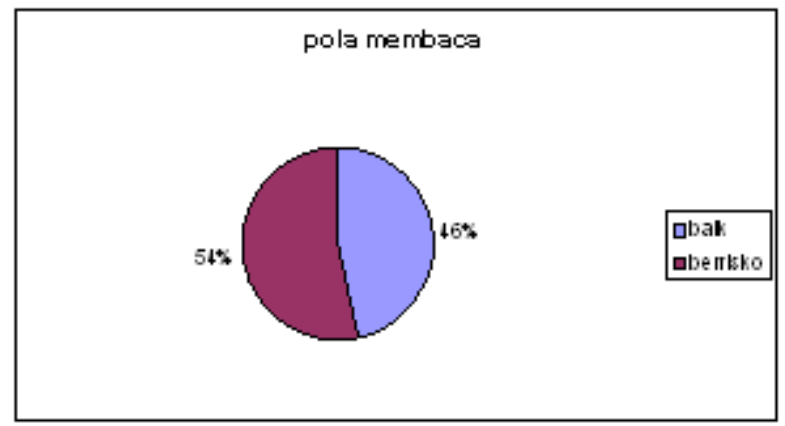

Gambar 3. Profil pola melihat dekat Mahasiswa FK UR 
Cut of point data akademik subyek penelitian adalah 2,99, berdasarkan cut of point tersebut digolongkan prestasi akademik cukup bila IPK kurang dari 2,99 dan prestasi akademik baik bila IPK lebih dari atau sama dengan 2,99 yang berjumlah 79 orang (52\%). Profil prestasi akademik subyek penelitian tercantum pada Gambar 4.

Untuk menilai ada tidaknya hubungan miopía dan prestasi akademik pada mahasiswa FK UR digunakan uji Chi square. Kemudian untuk melihat apakah miopía lebih sering ditemukan pada

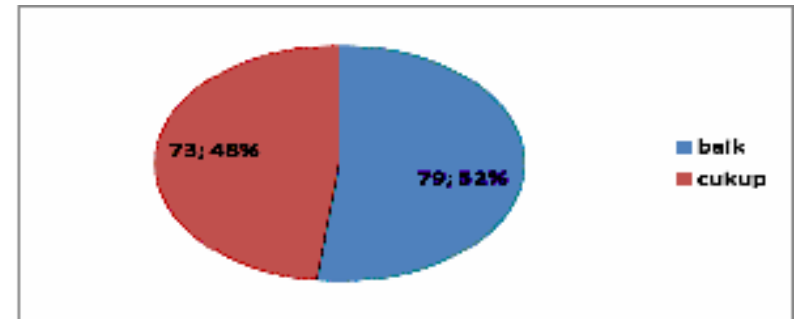

Gambar 4. Profil prestasi akademik Subyek Penelitian

mahasiswa yang mempunyai prestasi akademik baik digunakan rumus OR. Hasil uji statistik hubungan prestasi akademik dengan miopia disajikan pada Tabel 1.

Tabel.1 Hasil Uji Statistik Hubungan Prestasi akademik dengan Miopía

\begin{tabular}{|c|c|c|c|c|}
\hline \multirow[t]{2}{*}{ Fungsi Refraksi } & \multicolumn{2}{|c|}{$\begin{array}{c}\text { Prestasi } \\
\text { Akademik }\end{array}$} & \multirow[t]{2}{*}{$\begin{array}{c}\mathrm{OR} \\
95 \% \mathrm{CI}\end{array}$} & \multirow[t]{2}{*}{$\begin{array}{c}\mathrm{P} \\
\text { Value }\end{array}$} \\
\hline & Cukup & Baik & & \\
\hline Em etropia & $39(51,32 \%)$ & $37(48,68 \%)$ & 1,32 & 0,516 \\
\hline Miopia & $34(44,74 \%)$ & $42(55,26 \%)$ & & \\
\hline
\end{tabular}

Untuk menilai ada tidaknya hubungan miopía dan pola melihat dekat pada mahasiswa FK UR digunakan uji Chi square. Kemudian untuk melihat apakah miopía lebih sering ditemukan pada mahasiswa yang mempunyai pola melihat dekat digunakan rumus OR. Hasil uji statistik hubungan pola melihat dekat mahasiswa dengan miopia tertera pada Tabel 2:

Tabel 2. Hubungan pola Melihat dekat dengan Miopía

\begin{tabular}{ccccc}
\hline Fungsi Refraksi & \multicolumn{2}{c}{ Pola Melihat dekat } & \multirow{2}{O}{$\begin{array}{c}\text { PR } \\
\end{array}$} & $\begin{array}{c}\mathrm{P} \\
\text { Value }\end{array}$ \\
\cline { 2 - 3 } & brik & berisiko & & \\
\hline emetropia & $51(67,10 \%)$ & $25(32,90 \%)$ & 6,12 & 0,000 \\
Miopia & $19(25,00 \%)$ & $57(75,00 \%)$ & & \\
\hline Total & 70 & 82 & & \\
\hline
\end{tabular}

\section{PEMBAHASAN}

Hasil penelitian di FK UR menunjukkan bahwa dari 242 orang mahasiswa terdapat 82 orang $(33,9$ $\%)$ yang menderita kelainan refraksi. Kelainan refraksi yang diderita sebagian besar berupa miopía 76 orang $(92,68 \%)$. Kelainan refraksi pada 128 mahasiswa fakultas Kedokteran Singapura pada tahun 2004 tercatat $89,8 \%$ miopía, $1,3 \%$ hipermetropia, dan $82,2 \%$ astigmatisma. ${ }^{9}$ Sebaliknya pada mahasiswa fakultas Kedokteran di Denmark dan Norwegia prevalensi miopía relatif rendah yaitu 50\% dan 50,3\%. Perbedaan kelainan refraksi pada mahasiswa fakultas kedokteran pada beberapa negara berbeda-beda, hal ini mungkin disebabkan oleh variasi etnik dan predisposisi 
genetik, tetapi secara umum diyakini bahwa faktor lingkungan dan genetik merupakan dua faktor yang berperanan penting. Penelitian pada populasi di Amerika, Eropa, dan Australia menunjukkan bahwa kejadian miopía 8 kali lebih tinggi pada usia muda, sedangkan kejadian hipermetropia lebih tinggi 4,24,7 kali lebih tinggi pada usia tua. ${ }^{10}$

Berdasarkan Gambar 1.1 sebagian besar $(67 \%)$ mahasiswa FK UR yang menderita miopia tergolong kelainan miopia ringan yaitu miopia yang kurang dari 3 dioptri, $27 \%$ miopia sedang yaitu miopia antara 3-6 dioptri , dan $6 \%$ miopia berat yaitu miopia yang lebih dari 6 dioptri. Penelitian pada mahasiswa fakultas kedokteran di Singapura menunjukkan miopía berat terdapat pada $28,7 \% .^{11}$

Gambar 2. Menunjukkan bahwa mahasiswa yang berkacamata pada umur kurang dari atau pada umur 15 tahun terdapat pada $46 \%$ subyek penelitian. Onset miopía juvenile sebagian besar mulai dikeluhkan pada umur 8-14 tahun dan semakin banyak pada umur 1516 tahun. ${ }^{9}$ Umumnya anak-anak tidak sadar mereka menderita miopía, mereka menyatakan kabur ketika melihat benda dalam jarak jauh, bahkan tidak jarang miopía terdiagnosis melalui laporan orang tua atau guru yang melihat anak-anak mengecilkan matanya saat melihat jauh dan mempunyai perhatian yang baik saat duduk di depan. Berkembangnya miopía pada anakanak juga dipengaruhi oleh pertumbuhan fisik anak dan genetik.

Data penelitian menunjukkan 70 orang (46\%) mempunyai pola melihat dekat yang baik dan 82 orang $(54 \%)$ mempunyai pola melihat dekat berisiko. Berdasarkan cut of point mahasiswa yang digolongkan prestasi akademik cukup berjumlah 73 orang $(48 \%)$ dan prestasi akademik baik berjumlah 79 orang (52\%). Pada Tabel 1 terlihat bahwa mahasiswa yang mempunyai IPK baik dan menderita miopía berjumlah 42 orang $(55,26 \%)$, sedangkan yang mempunyai IPK baik tetapi tidak menderita miopía berjumlah 37 orang $(48,68 \%)$, hal ini menunjukkan bahwa orang yang mempunyai prestasi akademik baik memiliki kecenderungan lebih besar untuk menderita miopía . kenyataan ini sesuai dengan teori di mana orang yang mempunyai intelegensia baik mempunyai risiko lebih tinggi untuk menderita miopía. Telah lama diamati di beberapa Negara seperti Israel, Amerika, dan New Zealand bahwa Myopia pada anak sering terjadi pada anak yang mempunyai IQ yang tinggi.
Penjelasan tentang hal ini masih sangat terbatas. Diduga mungkin ada hubungan antara panjang sumbu bola mata dengan perkembangan otak, atau panjang sumbu bola mata dan IQ mungkin dipengaruhi oleh gen yang sama. ${ }^{7}$ Nilai OR yang diperoleh adalah 1,32 yang berarti bahwa mahasiswa yang mempunyai prestasi akademik baik mempunyai peluang 1,32 kali lebih besar untuk menderita miopía, akan tetapi prestasi akademik tidak menunjukkan hubungan yang signifikan dengan miopía $(\mathrm{p}$ value $=0,516)$. Tidak adanya hubungan miopia dengan prestasi akademik mahasiswa Fakultas Kedokteran UR mungkin disebabkan oleh banyaknya faktor lain yang mempengaruhi prestasi akademik, selain intensitas belajar, keefektifan belajar, faktor lingkungan sosial, dan lain-lain. Penelitian Saw menunjukkan inteligensia lebih berpengaruh terhadap terjadinya miopia dibandingkan pola melihat dekat. ${ }^{8}$

Tingginya prevalensi kelainan refraksi khususnya miopía pada mahasiswa fakultas kedokteran mungkin disebabkan oleh proses belajar di fakultas kedokteran yang lama dan intensif mendorong mahasiswa untuk bekerja dalam jarak dekat. Hasil penelitian menunjukkan bahwa sebagian besar remaja saat ini memiliki aktifitas yang kurang aktif. Mereka lebih banyak melakukan aktifitas yang bersifat menetap seperti menonton televisi dan video, serta main video game. ${ }^{8}$ Anakanak yang menderita miopía lebih banyak menggunakan waktunya untuk belajar, main komputer, dan menonton televisi. Penggunaan waktu dengan aktifitas visual seperti ini akan meningkatkan risiko untuk terjadinya kelainan refraksi. ${ }^{8}$ Waktu belajar yang lama di sekolah-sekolah terbukti mempertinggi angka myopia di Asia. Faktor keluarga selain berperan secara genetik, juga mempengaruhi kebiasaan membaca pada anggota keluarga. Orang tua yang menyukai membaca akan menularkan kebiasaan membaca pada anak-anaknya. Begitu pula kebiasaan rendahnya aktifitas fisik dan lebih menyukai menonton televisi juga mempengaruhi terjadinya kelainan refraksi. ${ }^{8}$

Dari tabel 2. didapatkan bahwa jumlah mahasiswa yang memiliki pola melihat dekat berrisiko dan menderita miopia adalah 57 orang $(75,00 \%)$, sedangkan mahasiswa yang memiliki pola melihat dekat berrisiko tetapi tidak mengalami kelainan refraksi berjumlah 25 orang $(32,90 \%)$. Uji 
statistik menunjukkan hubungan antara pola melihat dekat dengan terjadinya kelainan refraksi menunjukkan hasil yang sangat signifikan (nilai $\mathrm{p}$ d" 0,001). Nilai OR yang didapatkan adalah 6,12, hal ini berarti bahwa mahasiswa yang memiliki pola membaca berrisiko cenderung menderita miopía sebanyak 6,12 kali lebih besar dibandingkan mahasiswa dengan pola melihat dekat yang baik.

\section{KESIMPULAN}

Prevalensi miopía merupakan kelainan refraksi terbesar pada mahasiswa kedokteran UR. Dari data penelitian di dapatkan lebih banyak mahasiswa yang mempunyai pola melihat dekat berisiko dibandingkan mahasiswa yang mempunyai pola melihat dekat yang baik. Hasil uji statistik menunjukkan mahasiswa yang mempunyai prestasi akademik baik mempunyai peluang 1,32 kali lebih besar untuk menderita miopía, akan tetapi prestasi akademik tidak menunjukkan hubungan yang signifikan dengan miopía ( $\mathrm{p}$ value $=0,516$ ). Mahasiswa yang memiliki pola melihat dekat berrisiko menderita miopia sebanyak 6,12 kali lebih besar dibandingkan mahasiswa dengan pola melihat dekat yang baik. Terdapat hubungan yang sangat signifikan antara pola melihat dekat dengan terjadinya miopía (p d" 0,001).

Kepada masyarakat dianjurkan untuk memperbaiki pola melihat dekat untuk mencegah dan memperbaiki fungsi refraksi. Mengingat miopía dapat terjadi mulai dari usia anak-anak yang akan bertambah berat sampai usia dewasa, sebaiknya orang tua yang mempunyai anak usia sekolah mulai mengkombinasikan kegiatan anak-anaknya dengan kegiatan aktifitas fisik di luar ruangan.

\section{UCAPAN TERIMA KASIH}

Ucapan terima kasih penulis sampaikan pada mahasiswa fakultas kedokteran Universitas Raiu yang bersedia menjadi subyek penelitian. Terima kasih juga diucapkan pada staf non akademik di bagian fisiologi fakultas kedokteran Universitas Riau yang membantu dalam pelaksanaan penelitian ini.

\section{DAFTAR PUSTAKA}

1. Saw S, Chua WH, Hong CY, Wu HM, Chia KS,
Stone RA, et al. Heights and Its Relationship to Refraction and Biometry Parameters in Singapore Hildren : The latest Wisdom. Chinese children Investigative Ophthalmology \& Visual Science. $2002 ; 43: 11: 1408-1413$

2. Huynh SC, Robae D, Kifley A, Rose KA, Morgan IG, Wang JJ, et al. Ethnic Differences and Ocular Biometry in a population-Based Australian in Children . Eye Feb 2007. diakses 12 Februari 2007

3. Naidoo K., Case Finding in the Clinic: Refractive Errors. Journal of Community Eye Health $2002 ; 15: 43$. p39-40

4. Ilyas S. Pandangan Medical tentang Cacat Penglihatan. http://mitranetra.or.id diakses 1 oktober 2007

5. Hammond JC, Snieder H, Gilbert EC, Spector DT., Genes and Evironment in Refractive Error : The twin Eye Study. Investigative Ophthalmology \& Visual Science, May 2001, vol. 42 no6.

6. Zadnik K., Myopia and Hyperopia inChildren : The Latest Wisdom. Research to Prevent Blindness. Www.Rpbusa.Org. Di akses, 200702-15

7. Saw SM, Tan SB, Fung D, Chia KS, Kob D, Tan DTH, et. All. IQ and Assosiation with myoipia in Children. Investigative Ophthalmology \& Visual Science. $2004 ; 45$ : 9 : 2943-2948

8. Mutti OD, Michel GL, Moeschberger ML, Jones LA, Zadnik K, Parenteral Myopia, Near Work, School Achievement, and Children's Refrektive Error. Investigative Ophthalmology \& Visual Science. 2002; $43: 12: 3633-3640$

9. Saw SM, Chua WH, Gazzard G, Koh D, Tan DTH, Stone RA. Eye Growth Changes in Myopic Children in Singapore. BJO 2005: 1489-1494

10.Kempen HJ, Congdon GH, Friedman SD, O'Colmain JB. The Prevalence of Refractive Error Among Adults in The United States, Western Europe, and Australia. Arch Ophthalmol 2004; 122 .

11. Woo WW, lim KA, Yang H, Lim XY, Liew F, lee YS, et al. Refractive errors in medical students in Singapore. Singapore Med. J 2004; 45 : 10: 470 


\title{
Indeks Penulis (author) \\ Jurnal Ilmu Kedokteran Tahun ke-4 (Tahun 2010)
}

\author{
Andalas, Mohd., 1-9 \\ Ardelia, Patra Inova, 102-107 \\ Andrini, Fauzia, 102-107, 116-122 \\ Arfianti, 123-132 \\ Asni, Enikarmila, 30-35, 95-101 \\ Chandra, Fifia, 20-29 \\ Citra, Bevi Dewi, 133-140 \\ Fatmawati, 36-41 \\ Hamidy, Muhammad Yulis, 30-35, 95-101, 102-107 \\ Harapan, 1-9 \\ Haslinda, Lilly, 14-19 \\ Masdar, Huriatul, 56-64, 79-88 \\ Inayah, 42-47 \\ Ismawati, 48-55, 123-132 \\ Lesmana, Suri Dwi, 10-13, 14-19, 89-94, 108-115 \\ Masria, Sadeli, 116-122 \\ Nazriati, Elda, 123-132, 141-145 \\ Putri, Dwi Julianika, 108-115, \\ Restuastuti, Tuti, 20-29, 108-115, 133-140 \\ Safitri, Ira, 42-47 \\ Sitompul, Hermes C. , 133-140 \\ Sudigdoadi, Sunarjati, 116-122 \\ Supali, Taniawati, 71-78 \\ Supardi, Imam, 116-122 \\ Wahyuni, Sri, 48-55 \\ Wibowo, Heri, 71-78 \\ Wijaya, Chandra, 36-41, 141-145 \\ Wirna, Nora, 48-55 \\ Yolazenia, 14-19, 65-69, 71-78 \\ Zahtamal, 20-29, 65-69 \\ Zulinda, Aprilia, 65-69
}




\section{Indeks Subjek \\ Jurnal Ilmu Kedokteran Tahun ke-4 (Tahun 2010)}

\Acute toxicity test, 42

Aedes aegypti, 10, 12

Allergic diseases, 71

Antifungal activity, 102

Anti-inflammatory cytokines, 71

Anti dengue antibody, 36, 41

A.lumbricoides, 108, 109, 110, 111, 112, 113, 114

Bradyzoite, 89, 91, 92, 93, 94

Candida albicans, 102, 103, 104, 105, 106

Celery (Apium graveolens L.), 102

Central nervous system toxicity, 42

Coa gene, 117

Decubitus ulcer, 133

Dengue hemorrhagic fever, 36, 37, 38, 39, 40, 41

Effectiveness of two-hours repositioning, 133

Epstein barr virus, 79, 80, 81, 83, 84, 85

Esterase, 11, 12, 13

Genetical resistance, 11, 12, 13

Health behavior related to $\mathrm{MNCH}, 20$

Helminthiasis, 72

Helminthes infection, 14

IFN ${ }^{\wedge} ", 92,94$

IgE, 72, 73, 74, 76

IgG4, 71, 77

Immunopathogenesis, 79

Isotoma longiflora, 42, 43, 44, 46, 47

Lipid profile, 48,124

MNCH services, 20, 23, 24, 26, 29

Myopia, 141, 142, 143, 145

Nail's dirt, 141

Obesity, 123, 124, 125, 126, 127, 128, 129, 130

Organophosphate resistance, 10, 11, 12

PCR-RFLP, 117, 118, 119, 120

Pediculosis capitis, 65, 66, 67, 68

PlGF, 1, 2, 3, 4, 5, 6, 7

Post operative wound infection, 116, 117, 118, 119, 120

Preeclampsia, 1, 2, 5, 6

Problem-based learning, 30, 31, 32, 95, 96, 97, 98, 99, 100

Rheumatoid arthritis, 79, 82, 83, 84, 85

S.aureus, 116, 117, 118, 119, 120
sFlt-1 sEng, 1, 2, 3, 4, 7

Shallot (Allium ascalonicum L.), 48, 49

Similarity of strain, 116, 117

Spondyloarthritis, 56, 57

Stroke, 133, 135, 136

Students' participation, 30, 33, 95, 96, 97, 98, 99, 100

Synovial fluid, 56, 58, 60, 61, 62

TACE, 56, 57, 60, 61, 62

Tachyzoite, 89, 90, 91, 92, 93, 94

TGFâ-1, 1, 2, 3, 4,6, 7

TNF, 56, 58, 59, 60, 61, 62

TNFRs, 56, 58, 59, 60, 61, 62

Toxoplasma gondii, 89, 90, 91, 92, 93, 94

T.trichiura, 108, 109, 110, 111, 112, 113, 114

VEGF, 1, 2, 3, 4,6, 7 


\section{Daftar Nama Mitra Bestari \\ Sebagai Penelaah Ahli Jurnal Ilmu Kedokteran Tahun ke-4 (Tahun 2010)}

Untuk Penerbitan Tahun ke-4 (Tahun 2010), semua naskah artikel yang disumbangkan kepada Jurnal Ilmu Kedokteran telah ditelaah oleh para mitra bestari (peer reviewers) berikut ini:

1. dr. Widyandana, MHPE (Universitas Gadjah Mada Yogyakarta)

2. Prof. DR. Titania T. Nugroho, MS (Universitas Riau)

3. dr. Vitriana, SpRM (Universitas Padjadjajaran Bandung)

4. Prof. dr. Sudigdo Adi, $\operatorname{SpKK}(\mathrm{K})$ (Universitas Padjadjajaran Bandung)

5. Prof. DR. dr. Hj. Eryati Darwin, PA(K) (Universitas Andalas Padang)

6. dr. Hj. Sri Lestari KS, Sp.KK(K) (Universitas Andalas Padang)

7. Prof. DR. dr. Rizanda Mahmud, M.Kes (Universitas Andalas Padang)

8. dr. M. Yulis Hamidy, M. Kes, M.Pd.Ked (Universitas Riau)

9. dr. Donel Suheimi, SpOG-KFM (Universitas Riau/ RSUD Arifin Achmad Pekanbaru)

10. Prof. dr. Saleha Sungkar DAP\&E, MS, SpParK (Universitas Indonesia)

11. dr. Azizman Saad, Sp.P (Universitas Riau/ RSUD Arifin Achmad Pekanbaru)

12. DR. dr. Susy Tjahjani, M.Kes (Universitas Kristen Maranatha Bandung)

13. dr. Aziz Djamal, MSc, DMT\&H, SpMK (Universitas Andalas Padang)

14. Prof. dr. Fadil Oenzil, PhD (Universitas Andalas Padang)

15. Prof.dr.Khalilul Rahman,Sp.M(K) (Universitas Andalas Padang) 


\section{Petunjuk bagi Penulis Jurnal Ilmu Kedokteran (JIK) Journal of Medical Science}

1. Artikel yang ditulis untuk dimuat di Jurnal Ilmu Kedokteran (JIK) meliputi hasil penelitian, tinjauan pustaka dan laporan kasus di bidang kedokteran. Naskah diketik dengan huruf Times New Roman, ukuran 12 pts, dengan menggunakan spasi ganda (double), dicetak pada kertas A4 sepanjang maksimum 20 halaman, diserahkan dalam bentuk print-out sebanyak 3 eksemplar beserta soft copy-nya. Tulisan dibuat dalam format Microsoft Word. Pengiriman berkas dapat juga dilakukan melalui email sebagai attachment file yang dikirimkan ke alamat: jik bpk@ya-hoo.com

2. Nama penulis artikel dicantumkan tanpa gelar akademik dan ditempatkan di bawah judul artikel. Institusi asal penulis serta alamat coresponding author dapat dicantumkan pada catatan kaki.

3. Artikel ditulis dalam bahasa Indonesia atau Inggris dengan format esai, disertai judul pada masingmasing bagian artikel, kecuali bagian pendahuluan yang disajikan tanpa judul bagian. Judul artikel dicetak dengan huruf besar kecil tepi kiri, dengan huruf sebesar 14 poin. Peringkat judul bagian dinyatakan dengan huruf yang berbeda (semua judul bagian dan sub-bagian dicetak tebal atau tebal miring), dan tidak menggunakan angka/nomor pada judul bagian:

\section{PERINGKAT 1 (HURUF BESAR SEMUA, TEBAL, RATA TEPI KIRI)}

\section{Peringkat 2 (Huruf Besar kecil, Tebal, Rata Tepi Kiri) \\ Peringkat 3 ( Huruf Besar Kecil, Tebal-Miring, Rata Tepi Kiri)}

4. Sistematika artikel Tinjauan Pustaka (Jurnal Review) adalah: Judul; nama penulis (tanpa gelar akademik); abstrak (maksimum 100 kata); kata kunci; pendahuluan (tanpa judul) yang berisi latar belakang dan tujuan atau ruang lingkup tulisan; bahasan utama (dapat dibagi ke dalam beberapa sub-bagian); penutup atau kesimpulan; daftar rujukan (hanya memuat sumber-sumber yang dirujuk).

5. Sistematika artikel hasil penelitian adalah: judul; nama penulis (tanpa gelar akademik); abstrak (maksimum 150 kata) yang berisi tujuan, metode, hasil penelitian dan kesimpulan; kata kunci; pendahuluan (tanpa judul) yang berisi latar belakang, sedikit tinjauan pustaka, dan tujuan penelitian; metode; hasil; pembahasan; kesimpulan; ucapan terima kasih dan daftar rujukan(hanya memuat sumber-sumber yang dirujuk).

6. Sistematika laporan kasus adalah judul, abstrak, nama penulis (tanpa gelar akademik), laporan kasus, pembahasan, kesimpulan dan daftar rujukan

7. Sumber rujukan sedapat mungkin merupakan pustaka-pustaka terbitan 10 tahun terakhir. Rujukan yang diutamakan adalah sumber-sumber primer berupa laporan penelitian (termasuk skripsi, tesis, disertasi) atau artikel-artikel penelitian dalam jurnal dan/atau majalah ilmiah.

8. Perujukan dan pengutipan ditulis sesuai aturan Vancouver, diberi nomor urut sesuai dengan urutan pemunculan dalam keseluruhan teks, bukan menurut abjad. Cantumkanlah nama semua penulis bila tidak lebih dari 6 orang; bila lebih dari 6 orang penulis, tulis nama 6 penulis pertama diikuti et al. Jumlah rujukan sebaiknya dibatasi sampai 25 buah. Gunakan contoh yang sesuai dengan edisi ke 5 dari Uniform Requirements for Manuscript Submitted to Biomedical Journals yang disusun oleh International Commitee of Medical Journal Editors, 1977. Singkatan nama jurnal disesuaikan dengan Index Medicus. Hindarilah penggunaan abstrak sebagai rujukan. 
Untuk materi yang sudah dikirim untuk publikasi namun belum diterbitkan harus dirujuk dengan menyebutkannya sebagai pengamatan yang belum dipublikasi (Unpublished observation) seizin sumber. Makalah yang telah diterima namun belum terbit, dapat dirujuk dengan mencantum kata "in press".

9. Berikut adalah contoh cara menuliskan rujukan

\section{A Artikel standar}

Allen KJ, Soriano HE. Liver cell transplantation: the road to clinical application. J Lab Clin Med 2001;138:298-312.

Artikel yang lebih dari 6 penulis:

Block GD, Locker J, Bowen WC, Petersen BE, Katyal S, Strom SC, et al. Population expansion, clonal growth, and specific differentiation patterns in primary cultures of hepatocytes induced by HGF/SF, EGFand TGF alpha in a chemically defined (HGM) medium. J Cell

Biol1996;132:1133-1149.

Volume dalam suplemen

Iqbal K, Grundke-Iqbal I. Elevated levels of tau and ubiquitin in brain and cerebro-spinal fluid in Alzheimer's disease. Int Psychogeriatr 1997;9(Suppl. 1):289- 96.

\section{B Buku}

Penulis perseorangan

Murray CJL, Lopez A. The global burden of disease. Cambridge:Harvard University Press, 1996.

Editor sebagai penulis

Hilt W, Wolf DH, editors. Proteasomes: the world of regulatory proteolysis. George-town, Texas: Landes Bioscience;2000. p.1- 391.

Bab dalam buku

Bulatao RA, Stevens PW. Estimates and projections of mortality by cause: a global overview, 1970-2015. In: Jamieson DT, Mosley WH, Eds. Evolving health sector priorities in developing countries. Washington: Population, Health and Nutrition Division, The World Bank, 1989.

Organisasi sebagai penulis

The World Bank. World Development Report 1993. Investing in health. New York: Oxford University Press, 1993.

\section{Disertasi/ Tesis/ Skripsi}

Kaplan SJ. Post-hospital home health care: the elderly/access and utilization (disertasi). St. louis (MO): Washington Univ.; 1995

\section{Artikel dari Internet}

Morse SS. Factors in the emergence of infectious diseases. Emerg Infect Dis (serial online) 1995 Jan-Mar (dikutip 5 Juni 1995);1(1):[24 screen]. Available from: URL: HYPERLINK http: // www.cdc.gov/incidod/eid.htm

10. Tata cara pengutipan, rujukan, tabel, dan gambar mengikuti ketentuan dalam buku PEGANGAN: Gaya Penulisan, Penyuntingan dan Penerbitan Karya Ilmiah Indonesia karya Mien A. Rifai (2005) atau mencontoh tata cara yang digunakan dalam artikel yang telah dimuat. Penulisan istilah Bahasa Indonesia sesuai dengan Pedoman Umum Ejaan Bahasa Indonesia yang Disempurnakan (Depdikbud, 1987). Artikel berbahasa Inggris menggunakan ragam baku. 
11. Semua naskah ditelaah secara anonim oleh mitra bestari (reviewers) yang ditunjuk oleh penyunting menurut bidang kepakarannya. Penulis diberikan kesempatan untuk memperbaiki naskah atas dasar rekomendasi/saran dari mitra bestari atau penyunting. Kepastian pemuatan atau penolakan naskah akan diberitahukan secara tertulis.

12.Pemeriksaan dan penyuntingan cetak-coba dikerjakan oleh penyunting dan/atau dengan melibatkan penulis. Artikel yang sudah dalam bentuk cetak-coba dapat dibatalkan pemuatannya oleh penyunting jika diketahui bermasalah.

13.Segala sesuatu menyangkut perijinan pengutipan atau penggunaan software komputer untuk pembuatan naskah atau ihwal lain yang terkait dengan HAKI yang dilakukan oleh penulis artikel, berikut konsekuensi hukum yang mungkin timbul karenanya, menjadi tanggung jawab penulis artikel tersebut.

14.Sebagai prasyarat bagi pemrosesan artikel, para penyumbang artikel wajib menjadi pelanggan minimal selama setahun. Penulis yang artikelnya dimuat wajib membayar kontribusi biaya cetak sebesar Rp. 250.000,00 (dua ratus lima puluh ribu rupiah) perjudul. Sebagai imbalannya, penulis menerima nomor bukti pemuatan sebanyak 2 (dua) eksemplar dan cetak lepas sebanyak 2 (dua) eksemplar. Artikel yang tidak dimuat tidak akan dikembalikan, kecuali atas permintaan penulis.

Makalah dapat dikirimkan kepada:

Penyunting/Editor Jurnal Ilmu Kedokteran

Jl. Diponegoro No. 1

Pekanbaru 28111

Indonesia 